\title{
Carbon Dioxide Electrolysis for a Carbon-recycling Iron-making System
}

\author{
Arnoldus Lambertus DIPU, ${ }^{1) *}$ Junichi RYU ${ }^{2)}$ and Yukitaka KATO ${ }^{21}$ \\ 1) Department of Nuclear Engineering, Tokyo Institute of Technology, 2-12-1 Ookayama, Meguro-ku, Tokyo, $152-8550$ Japan. \\ 2) Research Laboratory for Nuclear Reactors, Tokyo Institute of Technology, 2-12-1 Ookayama, Meguro-ku, Tokyo, $152-8550$ Japan.
}

(Received on January 25, 2012; accepted on June 18, 2012)

\begin{abstract}
A new energy transformation system based on carbon recycling has been proposed; it is called the active carbon recycling energy system (ACRES) and has been developed in order to reduce the emission of carbon dioxide $\left(\mathrm{CO}_{2}\right)$ to the atmosphere. An experimental study based on the ACRES concept for carbon monoxide (CO) regeneration via high-temperature electrolysis of $\mathrm{CO}_{2}$ was carried out using several solid oxide electrolysis cells (SOECs). Experimental results showed that a cell with the structure Pt-LSM cermet|YSZ|Pt-LSM cermet exhibited the highest current density and CO production rates of $0.52 \mathrm{~mA} \cdot \mathrm{cm}^{-2}$ and $0.75 \mu \mathrm{mol} \cdot \mathrm{min}^{-1} \cdot \mathrm{cm}^{-2}$ respectively, at $900^{\circ} \mathrm{C}$. On the basis of the cell's electrolytic characteristics, the scale of a combined ACRES $\mathrm{CO}_{2}$ electrolysis/iron-making facility was estimated.
\end{abstract}

KEY WORDS: carbon dioxide; carbon monoxide; high temperature; electrolysis; SOECs; carbon recycling; iron-making system.

\section{Introduction}

The carbon content in the fossil fuels that are used as the primary energy resources that have sustained the economic growth of our society has caused a significant increase in the carbon dioxide $\left(\mathrm{CO}_{2}\right)$ concentration in the atmosphere. The excessive $\mathrm{CO}_{2}$ levels have disturbed the delicate balance in the atmosphere, resulting in an atmospheric accumulation of solar thermal energy attributed to the greenhouse gases; this causes the average temperature of the earth to rise and the global climate to change. ${ }^{1)}$ In Japan, the supply of fossil fuels used as primary energy resources depends mainly on imports. Energy in the imported fuels is $82 \%\left(18.9 \times 10^{18}\right.$ $\mathrm{J})$ of all the primary energy used in Japan. Here, $7 \%$ of the fossil fuel is consumed in the iron-making process. ${ }^{2)}$ Japan undertook the obligation to follow the Kyoto protocol and is required to drastically reduce its $\mathrm{CO}_{2}$ emissions. Any limit imposed on $\mathrm{CO}_{2}$ emissions will directly affect the manufacturing and service industries. To deal with this problem a new carbon recycling energy system has been proposed and developed in order to reduce the emission of $\mathrm{CO}_{2}$ into the atmosphere from industrial processes. In this new energy system, which is called the active carbon recycling energy system (ACRES), carbon is reused, cyclically consuming the $\mathrm{CO}_{2}$ emissions at a large industrial facility; thus, it can reduce the emission of $\mathrm{CO}_{2}$ to the atmosphere. ${ }^{2,3}$

A proposed application of ACRES to an iron-making process is shown in Fig. 1. The system is assumed to be ideal iron-making process. The system is powered by electricity and thermal energy generated from a high-temperature gas-

\footnotetext{
* Corresponding author: E-mail: dipu.a.aa@m.titech.ac.jp
} DOI: http://dx.doi.org/10.2355/isijinternational.52.1427 cooled reactor (HTGR). The regenerated carbon monoxide (CO) is recycled and used for the reduction of iron oxide into pure iron. $\mathrm{CO}_{2}$ produced by the reduction process is regenerated into $\mathrm{CO}$ by the $\mathrm{CO}_{2}$ electrolysis process using energy from the HTGR. Oxygen $\left(\mathrm{O}_{2}\right)$, a by-product of the $\mathrm{CO}$ regeneration process, can be a useful material for other oxidation processes. One promising aspect of $\mathrm{CO}$ regeneration using ACRES is that $\mathrm{CO}_{2}$ electrolysis using a solid oxide electrolysis cell (SOEC) occurs at high temperatures. Figure 2 shows the principal structure of an SOEC. $\mathrm{CO}_{2}$ is fed to the cathode side and diffused through a layer of cathode material to the cathode-electrolyte interface where it is decomposed into $\mathrm{CO}$ and oxygen ions $\left(\mathrm{O}^{2-}\right)$ by the input of electrons $\left(e^{-}\right)$. The $\mathrm{CO}$ molecules generated in the cathode side are collected, while the $\mathrm{O}^{2-}$ ions permeate through the dense electrolyte to the anode side. At the anode-electrolyte interface, the $\mathrm{O}^{2-}$ ions are oxidized to form $\mathrm{O}_{2}$ and electrons. The electrons are transported to the cathode through the

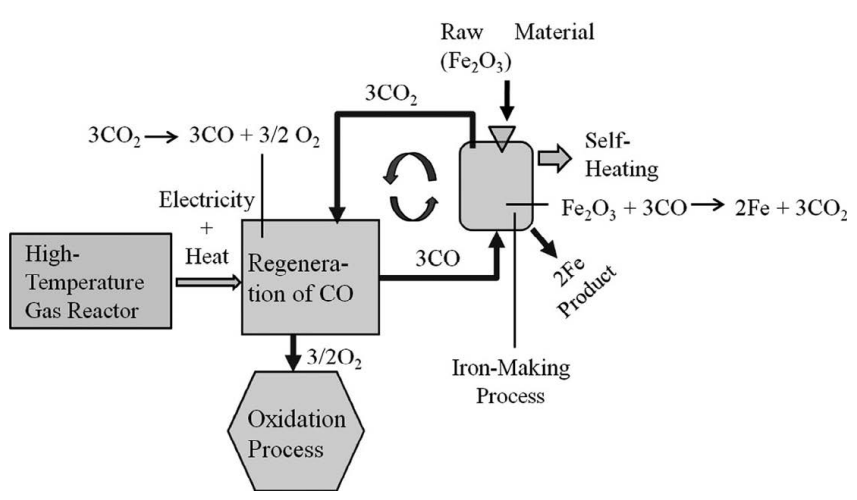

Fig. 1. Schematic of the ACRES concept as applied to the ironmaking process. 


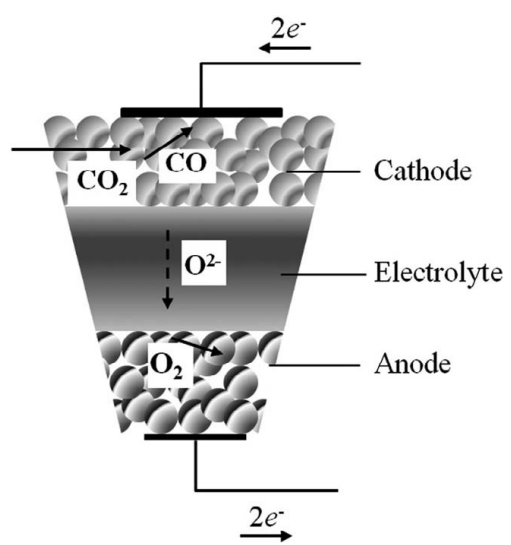

Fig. 2. The $\mathrm{CO}_{2}$ electrolysis process in the SOEC.

external circuit to complete the cycle. The reactions involved in $\mathrm{CO}_{2}$ electrolysis by an SOEC can be expressed as follows:

$$
\begin{aligned}
& \text { Cathode: } \mathrm{CO}_{2}+2 e^{-} \rightarrow \mathrm{CO}+\mathrm{O}^{2-} . \\
& \text { Anode: } \mathrm{O}^{2-} \rightarrow 0.5 \mathrm{O}_{2}+2 e^{-} \ldots \ldots \\
& \text { Total reaction: } \mathrm{CO}_{2} \rightarrow \mathrm{CO}+0.5 \mathrm{O}_{2} .
\end{aligned}
$$

The energy change for the reaction in Eq. (3) is given by

$$
\Delta \mathrm{H}=\Delta \mathrm{G}+\mathrm{T} \Delta \mathrm{S} .
$$

where $\mathrm{T}$ is the absolute temperature; $\Delta \mathrm{H}$, the enthalpy change; and $\Delta \mathrm{G}$, the Gibb's free energy. $\mathrm{T} \Delta \mathrm{S}$ can be considered as the amount of thermal energy required to reduce $\mathrm{CO}_{2}$ to $\mathrm{CO}$.

As shown in Fig. 2, electrolysis is performed by applying a sufficient electric potential to the SOEC. The procedure was carried out experimentally on the basis of the ACRES concept for $\mathrm{CO}$ regeneration via high-temperature electrolysis of $\mathrm{CO}_{2}$ and $\mathrm{CO}$ regeneration by a SOEC was demonstrated. As yet, SOECs have attracted much interest owing to their high efficiency in producing $\mathrm{H}_{2}$ and other synthetic fuels via high-temperature processes. ${ }^{4-8)}$ The principal goal of this work is to investigate the performance of a $\mathrm{CO}_{2}$ electrolysis process that utilizes a tubular SOEC. Given the results of the SOEC experiments using different electrode materials, the performance of an ACRES system using the most effective SOEC electrode material is evaluated.

\section{Experimental}

An SOEC test apparatus, as described in Fig. 3, was built to study the performance of high-temperature electrolysis of $\mathrm{CO}_{2}$. This test apparatus enables the use of the gases $\mathrm{CO}_{2}$, $\mathrm{CO}, \mathrm{H}_{2}$, and $\mathrm{Ar}$ on the cathode side, while $\mathrm{O}_{2}$ and $\mathrm{N}_{2}$ can be used on the anode side.

\subsection{Cell Preparation}

In this study, three types of electrode materials, namely $\mathrm{La}_{0.8} \mathrm{Sr}_{0.2} \mathrm{MnO}_{3}$ (LSM) with a diameter of $1 \mu \mathrm{m}$, platinum in the form of Pt paste, and Pt-LSM in cermet form, were tested. These materials were attached to a $\mathrm{Y}_{2} \mathrm{O}_{3}-\mathrm{ZrO}_{2}$ (yttria-stabilized zirconia, YSZ), electrolyte tube and were structured as described below.

Cell-1 had a Pt-LSM cermet|YSZ|Pt-LSM cermet structure for the cathode|electrolyte|anode. The structures of

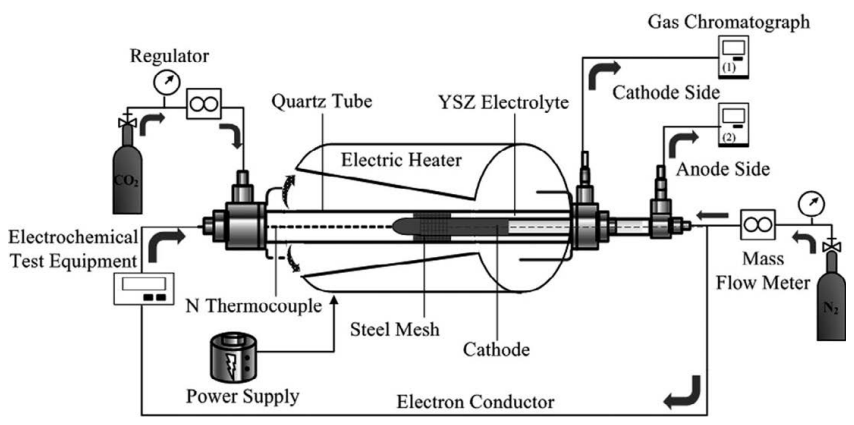

Fig. 3. Experimental SOEC apparatus for $\mathrm{CO}_{2}$ electrolysis.

Cells 2 and 3 were LSM|YSZ|LSM and Pt|YSZ|LSM, respectively. The outer and inner surfaces of YSZ tubes were used as the locations for the cathode and anode electrodes, respectively.

For Cell-1, the Pt-LSM cermet paste was prepared by mixing together $10.0 \mathrm{~g}$ LSM powder, $0.5 \mathrm{~g}$ Pt paste (TR7907 from Tanaka Kikinzoku Kogyo), 1.0 g binder, and 2.0 $\mathrm{g}$ dispersant. An appropriate amount of distilled water was added to the mixture. The binder and dispersant were added to the mixture to improve the adhesion to the electrolyte surface and to adjust the viscosity. The components were mixed thoroughly and the resulting paste was coated onto the cathode and anode sides by a dip-coating method. The electrolyte tube was composed of YSZ (ZR-8Y from Nikkato Corporation) and had outer (cathode) and inner (anode) diameters of $8 \mathrm{~mm}$ and $5 \mathrm{~mm}$, respectivley. The effective surface area for the cathode electrode was $25.1 \mathrm{~cm}^{2}$. The cell was then dried at room temperature for several hours before being light sintered at $800^{\circ} \mathrm{C}$ under inert atmosphere for $4 \mathrm{~h}$.

In the case of Cell-2, the LSM paste was prepared by mixing $10.0 \mathrm{~g}$ LSM powder (Powlex), $1.0 \mathrm{~g}$ binder, $2.0 \mathrm{~g}$ dispersant, and distilled water. The components of the mixture were dispersed with a dual-frequency ultrasonic cleaner. The resulting paste was coated onto the cathode and anode sides by a dip-coating method. The cell was then dried at room temperature for several hours and sintered at $1150^{\circ} \mathrm{C}$ under inert conditions for $4 \mathrm{~h}$.

In the case of Cell-3, platinum paste was used for the cathode. Here, $0.5 \mathrm{~g}$ of the paste was mixed with appropriate amounts of ethanol and binder. The mixture was dispersed by using an ultrasonic disperser. The resulting mixture was coated onto the cathode side surface of the YSZ tube by a dip-coating method. The LSM paste for the anode surface of Cell-3 was prepared using the same method as for the anode material prepared for Cell-2. After coating, the cell was then light sintered at $800^{\circ} \mathrm{C}$ under inert conditions for $4 \mathrm{~h}$ in order to remove any inorganic material that might have been present in the Pt paste.

\subsection{Electrolysis Process}

A stainless steel mesh (SUS 304) was used as the current collector. Electric current was supplied to the cell using a Galvanostat (Hokuto Denko HAL 3001). Prior to starting the electrolysis experiments, hydrogen reduction was performed as a pretreatment for each cathode for about $5 \mathrm{~h}$ at $800^{\circ} \mathrm{C}$. During the electrolysis process, pure $\mathrm{CO}_{2}$ at a flow rate of $25 \mathrm{~mL} \cdot \mathrm{min}^{-1}$ and argon at $25 \mathrm{~mL} \cdot \mathrm{min}^{-1}$ were supplied to the cathode while nitrogen at $25 \mathrm{~mL} \cdot \mathrm{min}^{-1}$ flowed into the 
anode. The $\mathrm{CO}$ and $\mathrm{O}_{2}$ production rates were analyzed using a gas chromatograph with a thermal conductivity detector (TCD).

\section{Results and Discussion}

3.1. Current Densities for Different Electrode Materials The relationships between the current density at the cathode side standard and the cell voltage during electrolysis at $900^{\circ} \mathrm{C}$ for Cell-1, Cell-2, and Cell-3 are shown in Fig. 4.

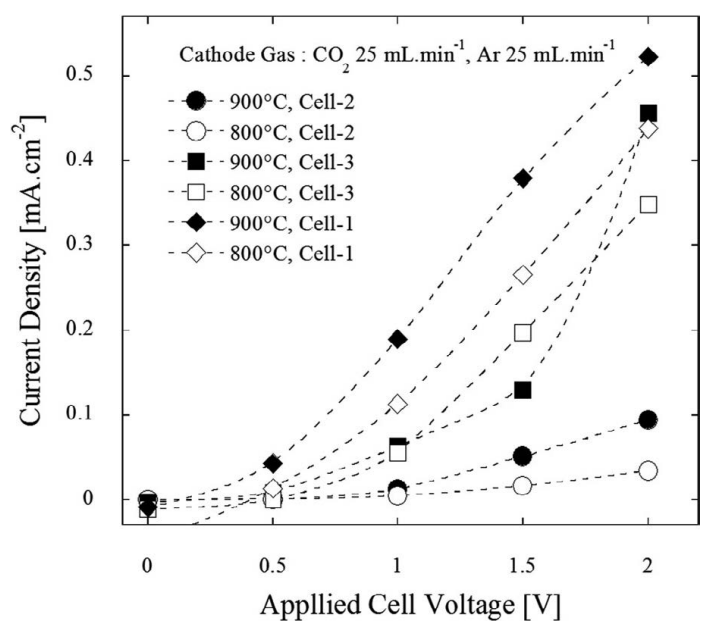

Fig. 4. Current density as a function of applied cell voltage for Cell-1, cell-2, and cell- 3 at $800^{\circ} \mathrm{C}$ and $900^{\circ} \mathrm{C}$.

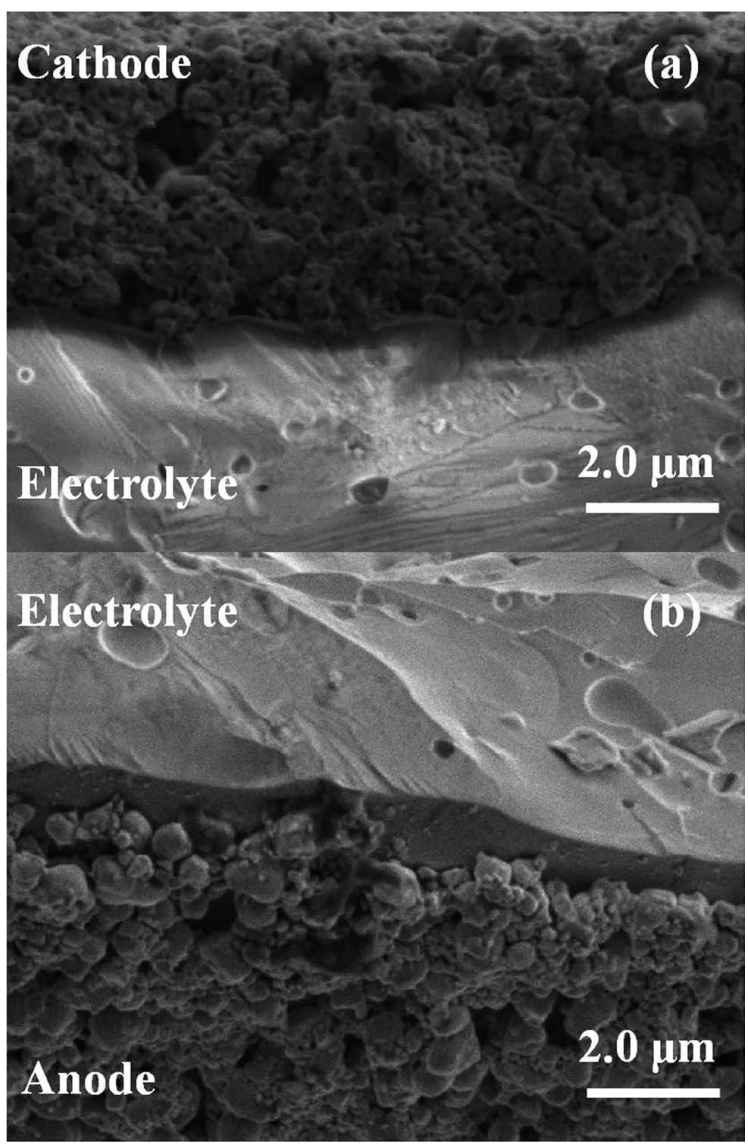

Fig. 5. SEM photographs of a cross section of Cell-1. (a) Interface between Pt-LSM cermet and YSZ electrolyte, cathode electrode and (b) interface between YSZ electrolyte and PtLSM cermet, anode electrode.
Current densities at the same applied cell voltage were strongly affected by the choice of electrode materials.

Cell-1 showed a higher current density of $0.52 \mathrm{~mA} \cdot \mathrm{cm}^{-2}$ compared to the current densities of Cell-2 and Cell-3. This may be attributed to the lower area specific resistance, as reported by Lohsoontorn et al., ${ }^{9)}$ in the Cell-1 electrode as compared with Cell-2 and Cell-3.

Furthermore, for Cell-2 and Cell-3, cathodic and anodic overpotentials might have caused high levels of resistance in the LSM cathode and anode electrodes. ${ }^{10,11)}$

The Pt-LSM cermet used for both the cathode and anode in Cell-1 exhibited the highest current density. The current density performance in Cell-1 was caused by the special structure of the Pt-LSM cermet electrodes. Since Pt has a low overpotential and LSM had good ionic conductivity and mechanical/chemical compatibility with the YSZ electrolyte, the mixture of $\mathrm{Pt}$ and LSM in the cermet form resulted in an improved current density for Cell-1. ${ }^{12}$ ) The similar coefficients of thermal expansion for the Pt-LSM cermet electrodes and the YSZ electrolyte helped to reduce contact resistance, which in turn reduced the cathode resistance and resulted in higher current density levels. Scanning electron microscope (SEM) micrographs showed that the Pt-LSM cermet cathode and anode were intact and adhered well to the YSZ electrolyte (see Fig. 5). No gap was found between cathode electrode-YSZ electrolyte interface and between anode electrode-YSZ electrolyte interfaces of Cell-1. Therefore, no delamination between electrodes and YSZ electrolyte was occurred at $800^{\circ} \mathrm{C}$ or $900^{\circ} \mathrm{C}$ which in turn resulted into higher current density of Cell-1. It was also suggested that during electrolysis, the Pt and LSM particles in the cermet form remained in good condition.

Observations of SEM micrographs of the cross sections

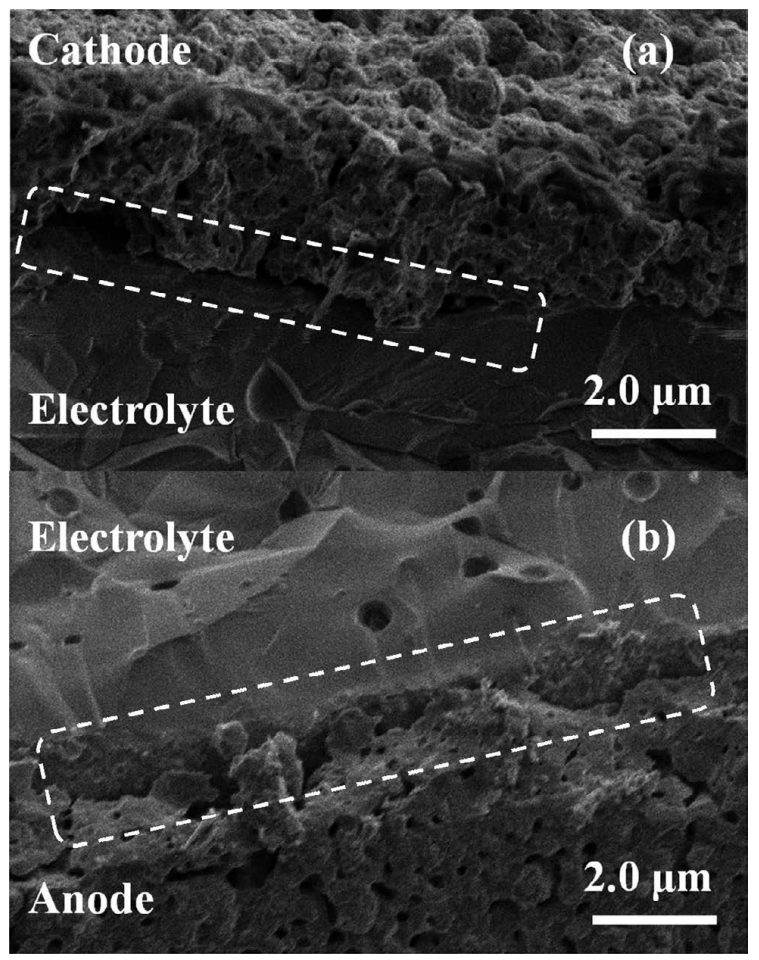

Fig. 6. SEM photographs of a cross section of Cell-2. (a) Interface between LSM and YSZ electrolyte, cathode electrode and (b) interface between YSZ electrolyte and LSM, anode electrode. 


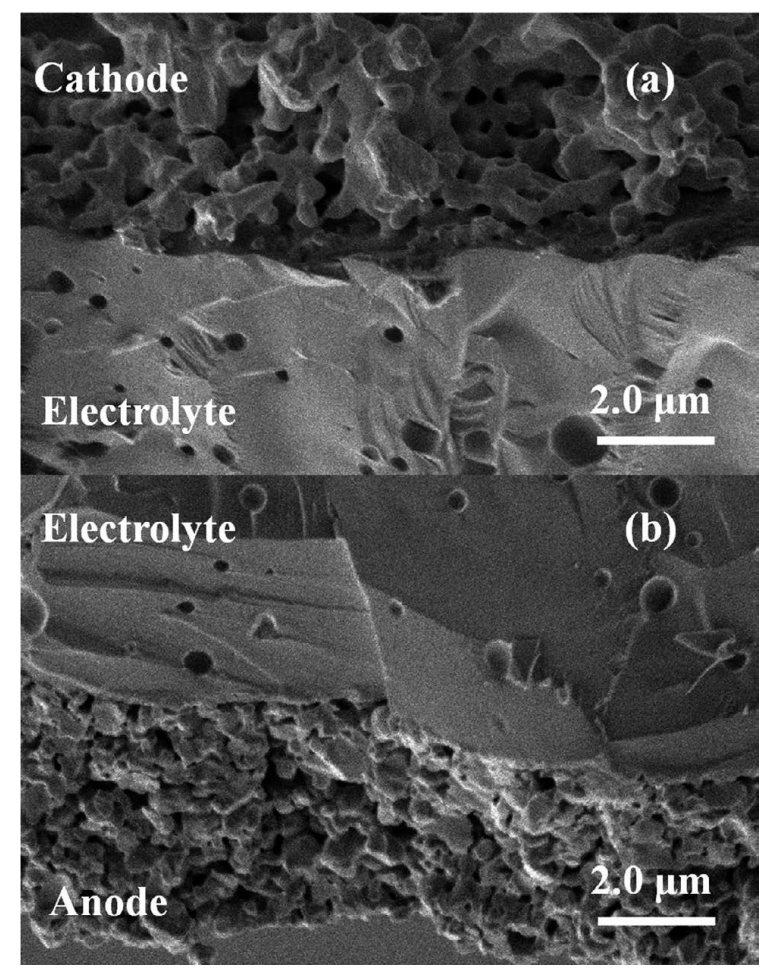

Fig. 7. SEM photographs of a cross section of Cell-3. (a) Interface between Pt and YSZ electrolyte, cathode electrode and (b) interface between YSZ electrolyte and LSM, anode electrode.

of Cell-2 after electrolysis (see Fig. 6) showed that small gaps had formed between the interfaces of both the cathode and anode electrodes and the YSZ electrolyte. This indicated that delamination of the LSM and the YSZ electrolyte had occurred during electrolysis. The delamination of the LSM electrodes resulted in higher ohmic resistance in Cell2 and eventually resulted in low current densities. $\mathrm{Pt}$, the cathode material in Cell-3, has exhibited generally higher current densities in other SOEC electrolysis applications, ${ }^{13)}$ thus it showed higher current density . The SEM micrograph of the Cell-3 cross section in Fig. 7 showed that there was no gap along the interface between the LSM anode side and the electrolyte and therefore such delamination might not have occurred. Further, it was observed that Pt was intact and adhered well to the surface of the YSZ electrolyte.

Overall, the Cell-1 SOEC with Pt-LSM cermet electrodes had better performance and higher current density than in the case of Cell-2 and Cell-3.

\subsection{Effect of Operating Temperature on $\mathrm{CO}$ and $\mathrm{O}_{2}$ Production Rates}

Cell-1 exhibited the highest current density levels as it performed electrolysis. Therefore, it was chosen as the subject for further analysis of $\mathrm{CO}_{2}$ electrolysis in this study. Figure 8 shows the $\mathrm{CO}$ and $\mathrm{O}_{2}$ production rates for Cell-1 as functions of current density at $800^{\circ} \mathrm{C}$ and $900^{\circ} \mathrm{C}$. CO production rates at $900^{\circ} \mathrm{C}$ seemed to be proportional to the current passing through the cell. However, at $800^{\circ} \mathrm{C} \mathrm{CO}$ production was almost the same as that produced at $900^{\circ} \mathrm{C}$. There have been relatively few reports on cermet that contained a noble metal such as $\mathrm{Pt}$ or perovskite oxide $\left(\mathrm{LaMnO}_{3}\right.$ or $\left.\mathrm{SrMnO}_{3}\right)$. This was presumably due to the

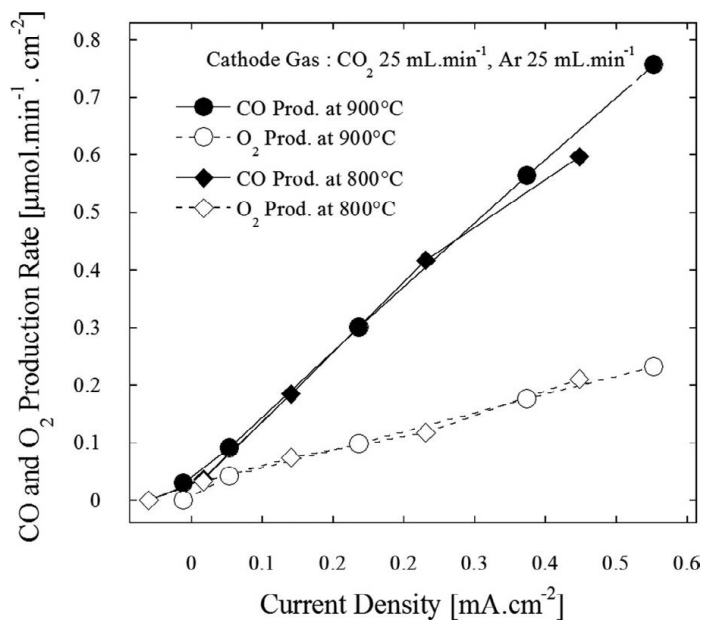

Fig. 8. $\mathrm{CO}$ and $\mathrm{O}_{2}$ production rates of Cell-1 as a function of current density at $800^{\circ} \mathrm{C}$ and $900^{\circ} \mathrm{C}$.

high cost of the noble metals. ${ }^{14)}$ However, as reported by Ni et al., ${ }^{15}$ the $\mathrm{Pt}$ electrode exhibited a lower overpotential resulting in a higher current density. The mixture of Pt and LSM in cermet form for the cathode and anode electrodes in Cell-1 worked well under a high operating temperature. Both the ionic conduction and chemical kinetics of the $\mathrm{CO}_{2}$ decomposition reaction increased with increasing temperature. The highest $\mathrm{CO}$ production rate that occurred during this work was $0.75 \mu \mathrm{mol} \cdot \mathrm{min}^{-1} \cdot \mathrm{cm}^{-2}$, which was achieved at an operating temperature of $900^{\circ} \mathrm{C}$ and a current density of $0.52 \mathrm{~mA} \cdot \mathrm{cm}^{-2}$.

However, $\mathrm{O}_{2}$ production rates at $800^{\circ} \mathrm{C}$ and $900^{\circ} \mathrm{C}$ were invariant. It was predicted that the anode side was the ratedetermining step for $\mathrm{O}_{2}$ production during the electrolysis process. In addition, LSM in the anode has been reported to have poor ionic conductivity. Thereafter, it was assumed that a relatively small amount of $\mathrm{O}^{2-}$ ions permeated the anode and formed $\mathrm{O}_{2}$ molecules. In order to improve the reaction rate in the anode, the addition of YSZ into the LSM mixture would be required. The mixture of LSM and YSZ would improve the adhesion between the anode electrode and YSZ electrolyte. This improved adhesion would effectively increase the electrochemically active area of the LSM-YSZ-gas triple phase boundary. ${ }^{\text {5) }}$

\subsection{Relationship between Cell Voltage and the Produc- tion Ratio of $\mathrm{O}_{2} / \mathrm{CO}$}

The relationship between current density and the production ratio of $\mathrm{O}_{2} / \mathrm{CO}$ is shown in Fig. 9. The production ratio of $\mathrm{O}_{2} / \mathrm{CO}$ is close to the stoichiometric ratio of 0.5 .

At lower current density levels, the $\mathrm{O}_{2} / \mathrm{CO}$ production ratio was slightly higher. After passing the initial stage of $\mathrm{CO}_{2}$ electrolysis, the current density increased with increasing cell voltage and then the production ratio of $\mathrm{O}_{2} / \mathrm{CO}$ became stable and remained lower than the stochiometric ratio of 0.5 . This result also indicated that the reactions in Eqs. (1), (2) and (3) were proceeded mainly on the cell.

\subsection{Relationship between Cell Voltage and the $\mathrm{CO} /$ Electrons Mole Ratio}

According to the reaction in Eq. (1), during the decomposition process, $2 \mathrm{~mol}$ electrons are needed to decompose 


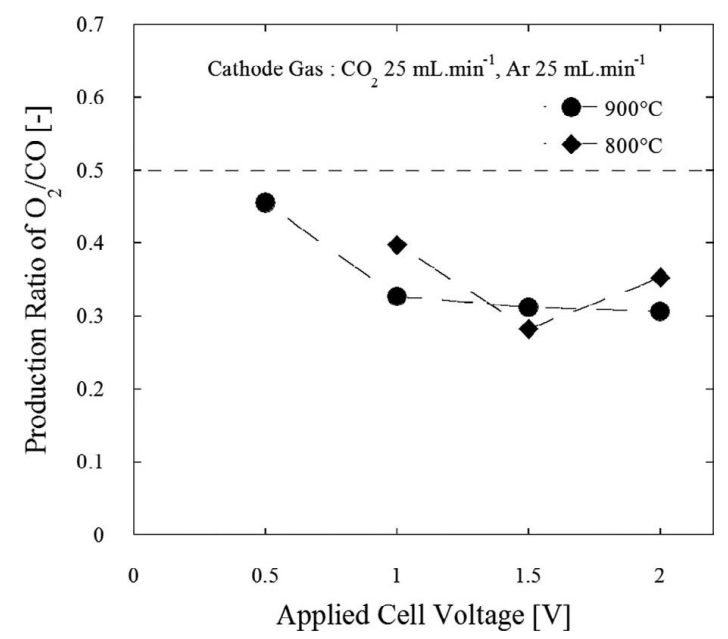

Fig. 9. Relationship between cell voltage and production ratio of $\mathrm{O}_{2} / \mathrm{CO}$ in Cell- 1 .

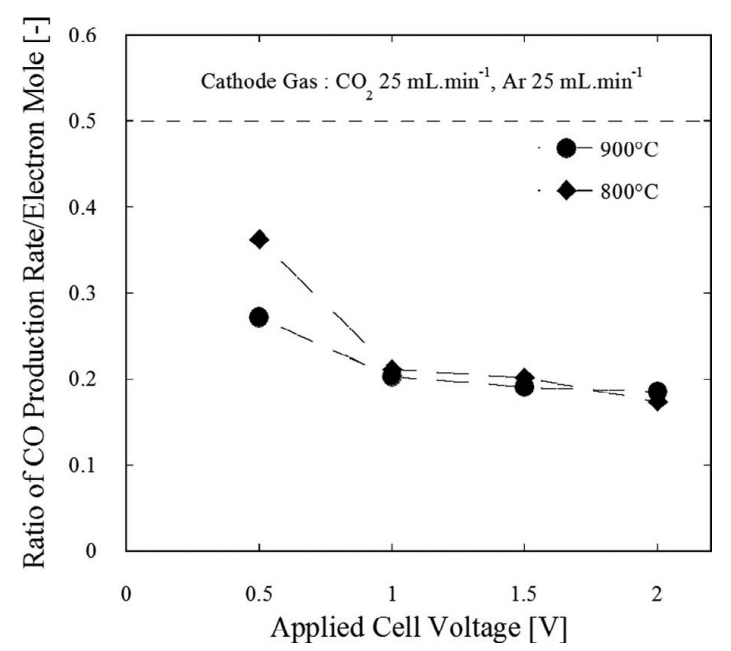

Fig. 10. Relationships between applied cell voltage and mole ratio of produced $\mathrm{CO}$ and electrons in Cell-1.

$1 \mathrm{~mol} \mathrm{CO}_{2}$ into $1 \mathrm{~mol} \mathrm{CO}$ and $\mathrm{O}^{2-}$. This means that the ratio between the $\mathrm{CO}$ produced and electrons flowing in will ideally be 0.5 . The relation between applied cell voltage and the mole ratio of Cell-1 is shown in Fig. 10. At lower applied cell voltage levels and corresponding lower current densities, the ratios were somewhat higher, close to 0.5 , than ratios at higher current densities. At higher voltage levels and higher current densities, the ratios decreased.

At lower applied voltages, electrons were consumed primarily for $\mathrm{CO}$ production. On the other hand, at higher voltage levels, electrons could be consumed in unknown reactions, and thus, the ratio was reduced. Carbonation would be one of the candidates for the unknown reaction:

$$
\mathrm{CO}+2 e^{-} \rightarrow \mathrm{C}+\mathrm{O}^{2-}
$$

The carbonation reaction will be discussed in the next study.

\subsection{Scale Estimation for an ACRES Facility}

A combined system with an ACRES $\mathrm{CO}_{2}$ electrolysis system using heat and power generated from an HTGR within an iron-making facility has been proposed ${ }^{2,3)}$ and is depicted in Fig. 11. An evaluation of such a combined system based on the experimental results for the Cell-1 SOEC provided

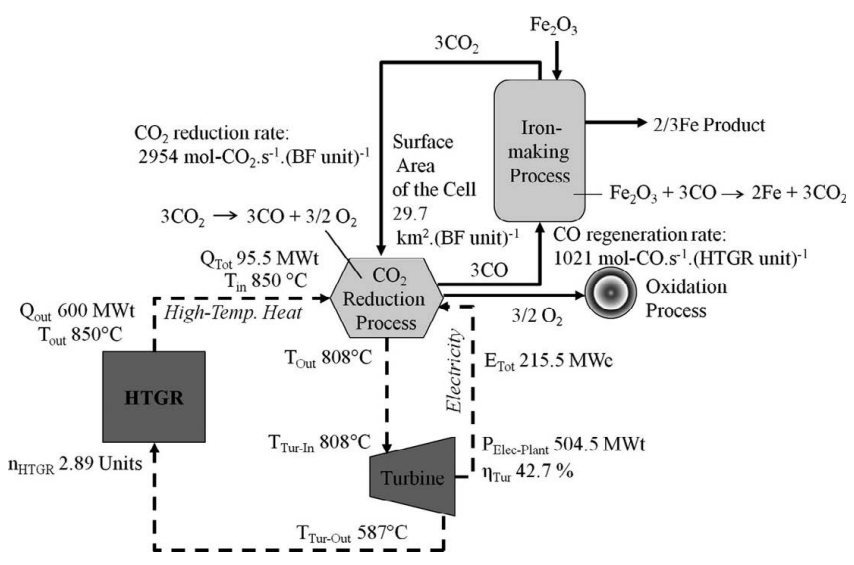

Fig. 11. Estimates of the scale of an ACRES carbon recycling system at an iron-making facility.

Table 1. Estimated ACRES energy balances for iron-making processes.

\begin{tabular}{|c|c|}
\hline Parameter & Values \\
\hline Electrolysis temperature for $\mathrm{SOEC}\left[{ }^{\circ} \mathrm{C}\right]$ & 800 \\
\hline $\begin{array}{l}\text { CO regeneration rate from SOEC experiment } \\
{\left[\mathrm{mol}-\mathrm{CO}^{-1} \mathrm{~s}^{-1} \cdot \mathrm{cm}^{-2}\right]}\end{array}$ & $9.94 \times 10^{-9}$ \\
\hline $\begin{array}{l}\text { Electricity demand for electrolysis of } \mathrm{CO}_{2} \text { at } 800^{\circ} \mathrm{C} \\
{\left[\mathrm{kJ} \cdot\left(\text { mol- }-\mathrm{CO}_{2}\right)^{-1}\right]^{3)}}\end{array}$ & 210.7 \\
\hline HTGR heat output rate $\left[\mathrm{MWt} \cdot(\mathrm{HTGR} \text { unit })^{-1}\right]$ & 600 \\
\hline $\begin{array}{l}\text { HTGR electricity output for } \mathrm{CO}_{2} \text { reduction } \\
{\left[\mathrm{MWe} \cdot(\text { HTGR unit })^{-1}\right]^{3)}}\end{array}$ & 215.5 \\
\hline $\begin{array}{l}\text { CO regeneration rate per an HTGR } \\
{\left[\text { mol-CO } \cdot \mathrm{s}^{-1} \cdot(\text { HTGR unit })^{-1}\right]^{3)}}\end{array}$ & 1021 \\
\hline $\begin{array}{l}\mathrm{CO}_{2} \text { emission rate from the crude iron production per } \\
\text { a blast furnace }\left[\mathrm{mol}_{-}-\mathrm{CO}_{2} \cdot \mathrm{s}^{-1} \cdot(\mathrm{BF} \text { unit })^{-1}\right]^{3)}\end{array}$ & 2954 \\
\hline $\begin{array}{l}\text { Electrode surface area per a blast furnace } \\
{\left[\mathrm{km}^{2} \cdot(\mathrm{BF} \text { unit })^{-1}\right]}\end{array}$ & 29.7 \\
\hline HTGR reactor units for a blast furnace [unit] & 2.89 \\
\hline
\end{tabular}

some estimates for the scale of the system. For the evaluation, it was assumed that electrolysis was performed at a high temperature using the high-temperature thermal output from the HTGR to first heat the electrolysis reaction cell and then be utilized for power production at the gas-turbine power generator. ${ }^{3)}$ The results of the energy balance evaluation for the combined system, taking into account the present SOEC experiment results, are shown in Table 1 and the estimated values are also indicated in Fig. 11.

The current density required for efficient electrolysis was $0.44 \mathrm{~mA} \cdot \mathrm{cm}^{-2}$ at $800^{\circ} \mathrm{C}$, based on the results of Cell-1 evaluation. A SOEC based on the Cell-1 electrodes could produce $9.94 \times 10^{-9} \mathrm{~mol} \cdot \mathrm{s}^{-1} \cdot \mathrm{cm}^{-2}$ of $\mathrm{CO}$. Electricity consumption for electrolysis at $2.0 \mathrm{~V}$ was $2.81 \mathrm{~mW} \cdot \mathrm{cm}^{-2}$. In the scale estimation, an HTGR providing $600 \mathrm{MW}$ of thermal output was able to produce enough power for high-temperature electrolysis in an ACRES. A conventional blast furnace (BF) for crude steel production in Japan emits an average of $1.12 \times$ $10^{4}$ ton- $\mathrm{CO}_{2} \cdot \mathrm{day}^{-1}$. When an HTGR was introduced into the combined system, 3 HTGR units were required for the hightemperature electrolysis reactions. It was estimated that about $29.7 \mathrm{~km}^{2}$. $\left(\mathrm{BF}\right.$ unit) ${ }^{-1}$ of cell surface area would be required to support $\mathrm{CO}$ regeneration by the system. 


\section{Conclusion}

Three $\mathrm{CO}_{2}$ electrolysis processes were demonstrated using different electrode materials on a YSZ-based electrolyte. Cell-1, with a structure of Pt-LSM cermet|YSZ|Pt-LSM cermet for the cathode|electrolyte|anode, had higher current density levels than those of Cell-2, with a LSM|YSZ|LSM structure, and Cell-3, with a Pt|YSZ|LSM structure. The CO production rate was higher at $900^{\circ} \mathrm{C}$ than at $800^{\circ} \mathrm{C}$. A CO production rate of $0.75 \mu \mathrm{mol} \cdot \mathrm{min}^{-1} \cdot \mathrm{cm}^{-2}$ was measured at an operating temperature of $900^{\circ} \mathrm{C}$ with a current density of $0.52 \mathrm{~mA} \cdot \mathrm{cm}^{-2}$. On the other hand, the $\mathrm{O}_{2}$ production rate was invariant at $800^{\circ} \mathrm{C}$ and $900^{\circ} \mathrm{C}$. It was thought that the anodic reaction was the rate-determining step for $\mathrm{O}_{2}$ production during the electrolysis process. The scale of a combined ACRES with $\mathrm{CO}$ regeneration by electrolysis of $\mathrm{CO}_{2}$ driven by an HTGR for an iron-making process was estimated on the basis of the experimental results. The required surface area of the SOEC cells was estimated to be 29.7 $\mathrm{km}^{2} \cdot(\mathrm{BF} \text { unit })^{-1}$ for a conventional BF. The reactivity of the cell has to be improved to reduce the necessary surface area. The combined system may contribute to the establishment of carbon supply security and a low-carbon society.

\section{REFERENCES}

1) Y. A. Cengel and M. A. Boles: THERMODYNAMICS, An Engineering Approach, McGraw-Hill, Singapore, (2007), 89.

2) Y. Kato: ISIJ Int., 50 (2010), 181.

3) Y. Kato, T. Obara, I. Yamanaka, S. Mori, A. L. Dipu, J. Ryu, Y. Ujisawa and M. Suzuki: Prog. Nucl. Energ., 53 (2011), 1017.

4) A. Brisse, J. Schefold and M. Zahid: Int. J. Hydrogen Energ., 33 (2008), 5375.

5) C. Yang, A. Coffin and F. Chen: Int. J. Hydrogen Energ., 35 (2010), 3221.

6) S. H. Jensen, X. Sun, S. D. Ebbesen, R. Knibbe and M. Mogensen: Int. J. Hydrogen Energ., 35 (2010), 9544.

7) S. D. Ebbesen and M. Mogensen: J. Power Sources, 193 (2009), 349.

8) Z. Zhan and L. Zhao: J. Power Sources, 195 (2010), 7250.

9) P. K. Lohsoontorn, D. J. L. Brett, N. Laosiripojana, Y.-M. Kim and J.-M. Bae: Int. J. Hydrogen Energ., 35 (2010), 3958

10) Y. Huang, J. M. Vohs and R. J. Gortez: Electrochem. Solid St., 9 (2006), No. 5, A237.

11) K. Chen and S. P. Jiang: Int. J. Hydrogen Energ., 36 (2011), 10541.

12) M. Liang, B. Yu, M. Wen, J. Chen, J. Xu and Y. Zhai: J. Power Sources, 190 (2009), 341.

13) T. Ishihara, N. Jirathiwathanakul and H. Zong: J. Royal Soc. Chem., 3 (2010), 665.

14) L. S. Wang and S. A Barnett: J. Solid State Ionics, 76 (1995), 103.

15) M. Ni, M. K. H. Leung and D. Y. C. Leung: Int. J. Hydrogen Energ., 33 (2008), 2337.

16) G. Tao, K. R. Sridhar and C. L. Chan: J. Solid State Ionics, 175 (2004), 615 . 